\title{
Synthesis, structural characterization and differential thermal analysis of the quaternary compound $\mathrm{Ag}_{2} \mathrm{MnSnS}_{4}$
}

\author{
G.E. Delgado ${ }^{a, *}$, N. Sierralta ${ }^{b}$, M. Quintero ${ }^{c}$, E. Quintero ${ }^{c}$, E. Moreno ${ }^{c}$, J.A. Flores-Cruz ${ }^{d}$ and C. Rincón ${ }^{c}$ \\ ${ }^{a}$ Laboratorio de Cristalografía, Departamento de Química, Facultad de Ciencias, \\ Universidad de Los Andes, Mérida, 5101, Venezuela. \\ ${ }^{b}$ Grupo de Teoría de la Materia Condensada, Departamento de Física, Facultad de Ciencias, \\ Universidad de Los Andes, Mérida 5101, Venezuela. \\ ${ }^{c}$ Centro de Estudios de Semiconductores, Departamento de Física, Facultad de Ciencias, \\ Universidad de Los Andes, Mérida 5101, Venezuela. \\ ${ }^{d}$ Centro de Investigación en Ciencia Aplicada y Tecnología Avanzada-Instituto Politécnico Nacional, \\ Ciudad de México, 11500, México. \\ *e-mail: gerzon@ula.ve
}

Received 18 August 2017; accepted 6 February 2018

\begin{abstract}
The quaternary chalcogenide compound $\mathrm{Ag}_{2} \mathrm{MnSnS}_{4}$ belonging to the system $\mathrm{I}_{2}$-II-IV-VI 4 and synthesized by the melt and anneal technique, was characterized by Rietveld refinement of the powder X-ray diffraction data and differential thermal analysis (DTA). It was found that $\mathrm{Ag}_{2} \mathrm{MnSnS}_{4}$ crystallizes in the orthorhombic space group $P m n 2_{1}$, with unit cell parameters $a=8.1705(5) \AA, b=6.9413(5) \AA, c=$ $6.6532(5) \AA$, and $V=377.33(5) \AA^{3}$, in a wurtzite-stannite structure. The DTA indicates that this compound melts at $790^{\circ} \mathrm{C}$ and that the phase relations which occurs in the material would be: $\alpha \rightarrow \alpha+\alpha_{1} \rightarrow \alpha_{1} \rightarrow \alpha_{1}+\beta \rightarrow \beta \rightarrow \beta_{1}+L \rightarrow L$, were $\alpha$ is the orthorhombic wurtzite-stannite Pmn $2_{1}$ structure; $\alpha_{1}$ is a high temperature modification; and $\beta$ and $\beta_{1}$ are the zinc-blende structure and its high-temperature modification, respectively.
\end{abstract}

Keywords: Chalcogenide; semiconductor; chemical synthesis; X-ray powder diffraction; crystal structure; differential thermal analysis.

PACS: 61.05.cp; 61.50.Nw; 61.66.Fn; 61.40.b

\section{Introduction}

The family of quaternary $\mathrm{I}_{2}$-II-IV-VI 4 compounds, where I = $\mathrm{Cu}$ or $\mathrm{Ag} ; \mathrm{II}=\mathrm{Zn}, \mathrm{Cd}, \mathrm{Mn}, \mathrm{Fe}$, or $\mathrm{Ni}$; IV = Si, Ge, or $\mathrm{Sn}$; and VI = S, Se, or Te; obtained from the tetrahedrally coordinated derivatives of the II-VI binaries [1], have received considerable attention lately mainly because they can be useful for their potential application as solar-cell absorbers [2-4], photocatalysts for solar water splitting [5] and thermoelectric materials [6-8]. In particular, chalcogenide tin-sulphide complex compounds are very promising for optoelectronics, which is a consequence of high electron-phonon anharmonicity for such kind of materials [9]. One of these materials, $\mathrm{Cu} 2 \mathrm{ZnSnS} 4$ has attracted great attention for photovoltaic devices because of its optimum direct band gap energy $(\sim$ $1.5 \mathrm{eV})$, large absorption coefficient $\left(\sim 10^{4-6} \mathrm{~cm}^{-1}\right.$, naturally abundant and environmentally friendly thin-film solarcell absorber [10,11]. These quaternaries fulfill the rules of adamantane compound formation, according to which the cation substitution is performed in such a way that the average number of valence electrons per atomic site and the ratio valence electrons to anions, which in diamond-like materials are four and eight, respectively, is preserved [1].

Structural studies carried out on some members of this family indicate that they crystallize in sphalerite or wurtzite derivative structures. In sphalerite derivatives with tetragonal symmetry: in a $\mathrm{Cu}_{2} \mathrm{FeSnS}_{4}$-type structure (stannite, space group $I \overline{4} 2 m$ ) or in a $\mathrm{Cu}_{2} \mathrm{ZnSnS}_{4}$-type structure (kesterite, space group $I \overline{4}$ ) [12]. In wurtzite derivatives with orthorhombic symmetry: in a $\mathrm{Cu}_{2} \mathrm{CdGeS}_{4}$-type structure (wurtzitestannite, space group $P m n 2_{1}$ ) [13] or with monoclinic symmetry (wurtzite-kesterite, space group $P n$ ) [14]. These crystallographic forms are very close to each other with the only difference in the distribution of the cations in the tetrahedral sites (see Fig. 1). Recently, Chen et al. [15,16] have shown that there is a clear relationship between the properties of the wurtzite-kesterite and kesterite structures, as well as between wurtzite-stannite and stannite structures.

Several recent studies on the structural characterization and physical properties, including transport properties, of these $\mathrm{Cu}_{2}$-II-IV-VI 4 [17-28] and $\mathrm{Ag}_{2}$-II-IV-VI 4 [29-35] quaternary semiconductor chalcogenides have been reported.

On the other hand, $\mathrm{I}_{2}-\mathrm{II}-\mathrm{IV}-\mathrm{VI}_{2}$ semiconducting compounds in which the II cation is a paramagnetic ion, as $\mathrm{Mn}^{+2}$, $\mathrm{Fe}^{+2}, \mathrm{Co}^{+2}$ or $\mathrm{Ni}^{+2}$, known as semimagnetic materials, have also received considerable attention because magneto-optical effects larger than those observed in $\mathrm{II}_{1-x} \mathrm{Mn}_{x}-\mathrm{V}_{I 2}$ alloys could be obtained in such quaternaries [36]. One of them, $\mathrm{Ag}_{2} \mathrm{MnSnS}_{4}$ could be of interest because it exhibits antiferromagnetic behavior [37]. Concerning to its crystal structure, discrepancy exists in the scarce information reported the literature. According to Lamarche et al. [37], this compound crystallizes with orthorhombic symmetry and unit cell parameters $a=8.019 \AA, b=6.964 \AA, c=6.527 \AA$, without defining its space group or structure. However, it has been more recently reported, with no structural details [38], that 

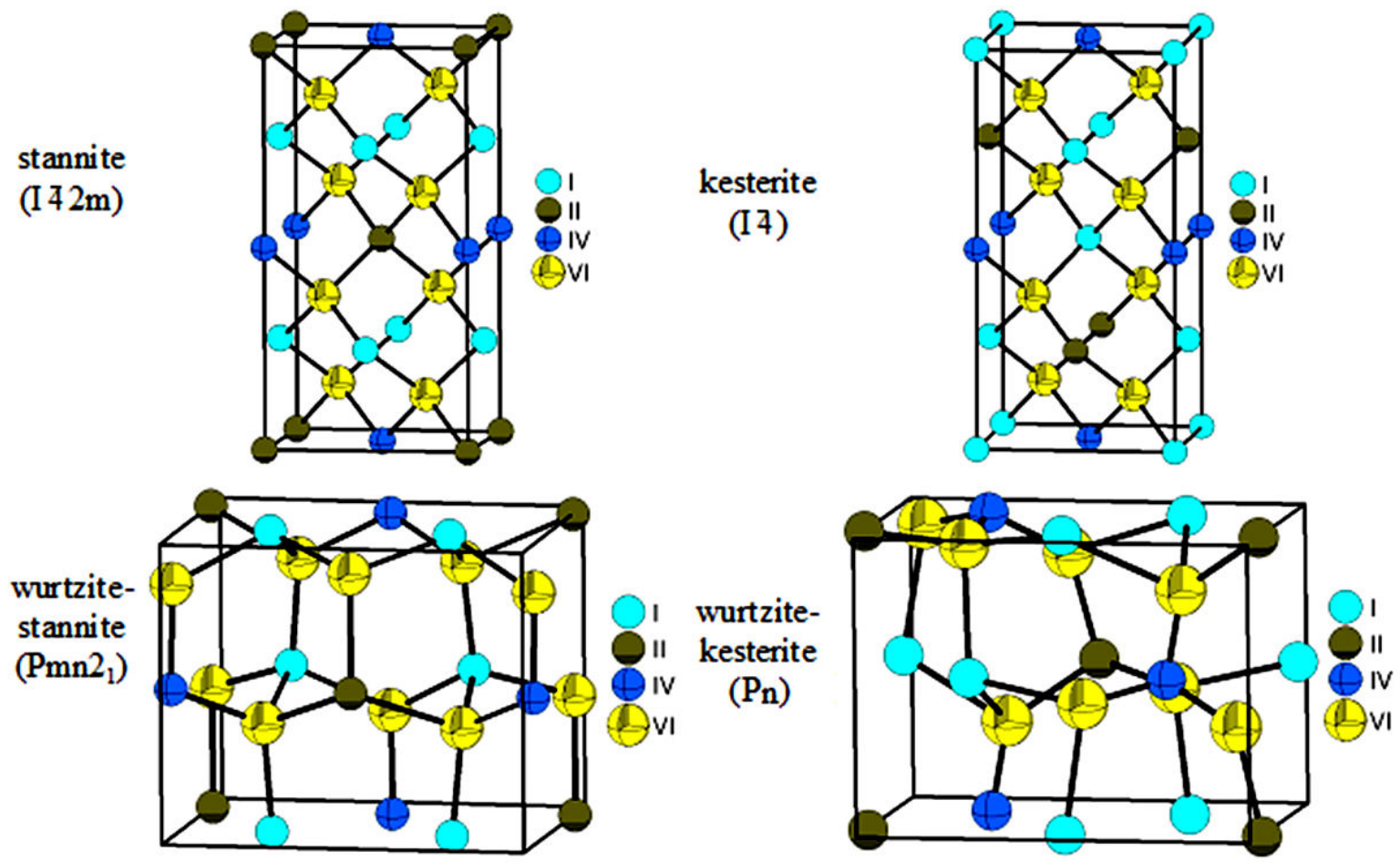

FIGURE 1. Unit cell diagram of the stannite, kesterite, wurtzite-stannite and wurtzite-kesterite structures showing the cation and anion distribution in the $\mathrm{I}_{2}-\mathrm{II}-\mathrm{IV}-\mathrm{VI}_{4}$ family of compounds.

$\mathrm{Ag}_{2} \mathrm{MnSnS}_{4}$ crystallizes in the monoclinic space group $\mathrm{Pn}$, with unit cell parameters $a=6.696(1) \AA, b=6.991(1) \AA$, $c=8.222(2) \AA, \beta=90.00(3)^{\circ}$ (pseudo-orthorhombic).

Furthermore, $\mathrm{Ag}_{2} \mathrm{MnSnS}_{4}$ is one of the three sulfide minerals containing silver and tin found in nature. They are the hocartite, $\mathrm{Ag}_{2} \mathrm{FeSnS}_{4}$, found in Bolivia in 1967 [39], the pirquitasite, $\mathrm{Ag}_{2} \mathrm{ZnSnS}_{4}$, found in Argentina in 1980 [40], and the agmantinite, $\mathrm{Ag}_{2} \mathrm{MnSnS}_{4}$, found in Perú in 2014 [41], whose name has been recently approved by the Commission on New Minerals, Nomenclature and Classification of the International Mineralogical Association [41].

In view of the considerable importance of such semimagnetic compound, in this work we report the synthesis, thermal analysis and crystal structure characterization of the $\mathrm{I}_{2}-\mathrm{II}-\mathrm{IV}$ $\mathrm{VI}_{4} \mathrm{Ag}_{2} \mathrm{MnSnS}_{4}$ semimagnetic compound.

\section{Experimental}

\subsection{Synthesis}

The sample was synthesized by the melt and anneals technique. Highly pure components (silver $99.98 \%$, manganese $99.97 \%$, tin $99.99 \%$, and sulphur 99.99) of $1 \mathrm{~g}$ sample were sealed under vacuum $\left(\approx 10^{-5}\right.$ Torr $)$ in a small quartz ampoule, and then the components were heated up to $200^{\circ} \mathrm{C}$ and kept for about 1-2 $\mathrm{h}$. The temperature was then raised to $500^{\circ} \mathrm{C}$ using a rate of $40^{\circ} \mathrm{C} / \mathrm{h}$, and held at this temperature for 14 hour. After, the sample was heated from $500^{\circ} \mathrm{C}$ to $800^{\circ} \mathrm{C}$ at a rate of $30^{\circ} \mathrm{C} / \mathrm{h}$ and kept at this temperature for another 14 hours. Then it was raised to $1150^{\circ} \mathrm{C}$ at $60^{\circ} \mathrm{C} / \mathrm{h}$, and the components were melted together at this temperature. The furnace temperature was brought slowly $\left(4^{\circ} \mathrm{C} / \mathrm{h}\right)$ down to $600^{\circ} \mathrm{C}$, and the sample was annealed at this temperature for 1 month. Finally, the sample was slowly cooled to room temperature using a rate of about $2^{\circ} \mathrm{C} / \mathrm{h}$.

\subsection{Chemical Analysis}

The stoichiometric relation of the sample was investigated by SEM technique, using a Hitachi S2500 microscope equipped with a Kedex EDX accessory. Three different regions of the ingot were scanned and the average atomic percentages are as follows: $\mathrm{Ag}(25.2 \%), \mathrm{Mn}(11.1 \%), \mathrm{Sn}(11.3 \%)$ and $\mathrm{S}$ $(52.4 \%)$. The error in standardless analysis was around $5 \%$. These values are in good agreement with the ideal composition $2: 1: 1: 4$

\subsection{Differential thermal analysis (DTA)}

Phase transition temperatures were obtained in the temperature range between 20 to $1150^{\circ} \mathrm{C}$, using a Perkin-Elmer DTA-7 with aluminum and gold used as reference materials. The charge was of powdered alloy of approximately $100 \mathrm{mg}$ weight. Both heating and cooling runs were carried out on each sample. The average rates of these runs being approximately $10^{\circ} \mathrm{C} / \mathrm{min}$. The error in determining these temperatures is of about $\pm 10^{\circ} \mathrm{C}$. 


\subsection{X-ray powder diffraction (XRPD)}

For the X-ray analysis, a small quantity of the sample, cut from the ingot, was ground mechanically in an agate mortar and pestle, and sieved to a grain size of less than $10 \mu \mathrm{m}$. The XRPD data was collected at 293(1) $\mathrm{K}$, in $\theta / \theta$ reflection mode using a Siemens D5005 diffractometer equipped with an Xray tube (CuK $\alpha$ radiation: $\lambda=1.5418 \AA ; 40 \mathrm{kV}, 30 \mathrm{~mA})$. The specimen was scanned from $10^{\circ}-80^{\circ} 2 \theta$, with a step size of $0.02^{\circ}$ and counting time of $10 \mathrm{~s}$. Quartz was used as an external standard.

\section{Results and Discussion}

\subsection{Differential thermal analysis}

DTA runs were carried out on the sample as indicated above. The transition temperatures as well as the type of melting were obtained from the peaks on the DTA heating and cooling curves. Each transition temperature was determined from the base intercept of the tangent to the leading edge of the peak in the differential signal. The value of the melting point temperature, denoted as TM, obtained from the peaks on the DTA curve, is given in Fig. 2, which shows the thermogram for $\mathrm{Ag}_{2} \mathrm{MnSnS}_{4}$.

Three transitions are observed in both heating and cooling runs. These appear at about 477,640 and $790^{\circ} \mathrm{C}$, and at about 973,700 and $592^{\circ} \mathrm{C}$, in these curves, respectively. It can also be seen, that the compound melts congruently at about $973^{\circ} \mathrm{C}$. Hence, the effect observed at $973^{\circ} \mathrm{C}$ corresponds to the transition from $\left(\mathrm{L}+\beta_{1}\right)$ to the liquid state $\mathrm{L}$. Here, $\beta_{1}$ is a zinc-blende (ZB) structure high-temperature modification. The effect observed at $790^{\circ} \mathrm{C}$ corresponds to the liquid-line, i.e., to the peritectic decomposition of the $\mathrm{Ag}_{2} \mathrm{MnSnS}_{4}$ from $\beta$ (other ZB phase high temperature modification) to $\mathrm{L}+\beta_{1}$. On the other hand, the peaks at 640 and $700^{\circ} \mathrm{C}$, in the heating

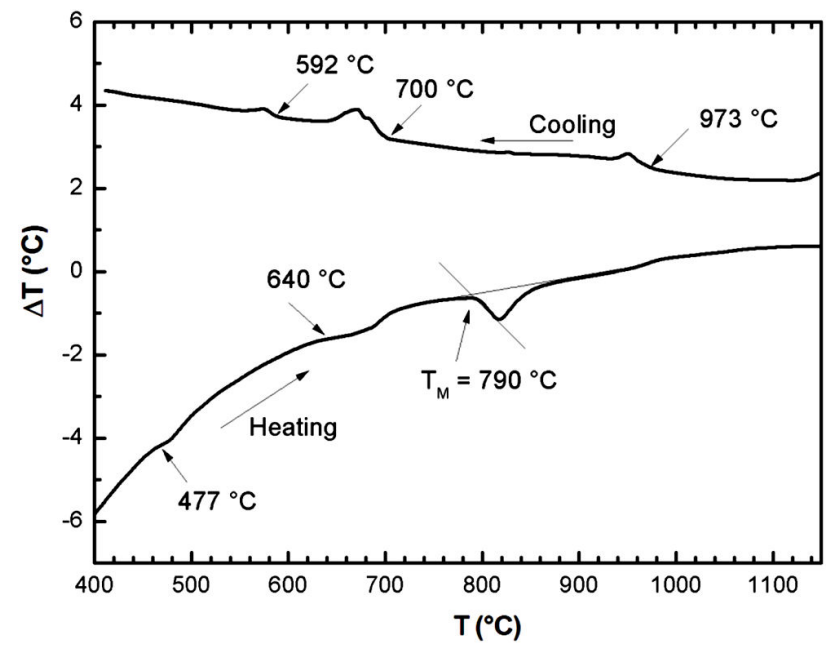

FIGURE 2. DTA thermogram for $\mathrm{Ag}_{2} \mathrm{MnSnS}_{4}$. The direction of heating run, or cooling run, is indicated by the corresponding arrow. curve, are related to the peritectic decomposition of the compound from $\alpha_{1}$, which is a wurtz-stannite phase high temperature modification, to $\beta+\alpha_{1}$, and to the solid-solid transformation from $\beta+\alpha_{1}$ to $\beta$, respectively. In addition, the peaks at 592 and $640^{\circ} \mathrm{C}$ correspond to the peritectic decomposition of the $\mathrm{Ag}_{2} \mathrm{MnSnS}_{4}$, from $\alpha_{1}+\alpha$ to solid $\alpha_{1}$, and to the transition from $\alpha_{1}$ to $\beta+\alpha_{1}$, respectively. The transition at about $477^{\circ} \mathrm{C}$, observed in heating curve, corresponds to the peritectic decomposition of the room temperature $\alpha-\mathrm{Ag}_{2} \mathrm{MnSnS}_{4}$ phase with wurtz-stannite $\left(P m n 2_{1}\right)$ structure, to $\alpha+\alpha_{1}$. Finally, the sequence of phase relations for this compound from low to high temperatures should be: $\alpha \rightarrow \alpha+\alpha_{1} \rightarrow \alpha_{1} \rightarrow \alpha_{1}+\beta \rightarrow \beta \rightarrow \beta_{1}+\mathrm{L} \rightarrow \mathrm{L}$.

\section{2. $\mathrm{X}$-ray powder diffraction analysis}

Figure 3 shows the resulting X-ray powder diffractogram for the $\mathrm{Ag}_{2} \mathrm{MnSnS}_{4}$ compound. The X-ray powder pattern show a single phase. The 20 first peak positions were indexed using the program Dicvol04 [42], which gave a unique solution in an orthorhombic cell with parameters $a=8.170(1) \AA$, $b=6.940(1) \AA$, and $c=6.650(1) \AA$. The lack of systematic absence condition $h+k+l$, in the general reflections of the type $h k l$, indicated a $P$-type cell. By analyzing the crystallographic characteristics of $\mathrm{Ag}_{2} \mathrm{MnSnS}_{4}$ with those of other $\mathrm{I}_{2}-\mathrm{II}-\mathrm{IV}-\mathrm{VI}_{4}$ related compounds, taking in account the sample composition, cell parameters and lattice-type, it is found that this material is isomorphic with $\mathrm{Ag}_{2} \mathrm{CdGeS}_{4}$ [29] which crystalize with wurtzite-stannite structure (space group $P m n 2_{1}$ ) [13]. So, in order to refine the structural parameters of $\mathrm{Ag}_{2} \mathrm{MnSnS}_{4}$, the space group $\operatorname{Pmn} 2_{1}\left(\mathrm{~N}^{\circ} 31\right)$ and the atomic position parameters of $\mathrm{Ag}_{2} \mathrm{CdGeS}_{4}$ were taken as the starting values.

The Rietveld refinement [43] was performed using the Fullprof program [44]. The indexed unit cell results were taken as starting parameters. The angular dependence of the peak full width at half maximum (FWHM) was described by

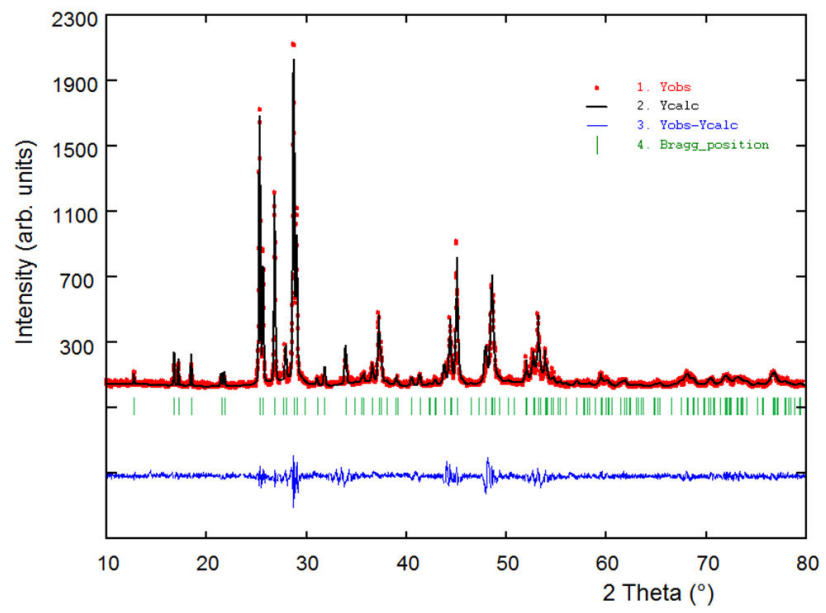

FIGURE 3. Final Rietveld plot showing the observed, calculated and difference pattern for the $\mathrm{Ag}_{2} \mathrm{MnSnS}_{4}$ compound. The Bragg reflections for both phases are indicated by vertical bars. 
TABLE I. Results of Rietveld refinement for $\mathrm{Ag}_{2} \mathrm{MnSnS}_{4}$.

\begin{tabular}{cccc}
\hline Molecular formula & $\mathrm{Ag}_{2} \mathrm{MnSnS}_{4}$ & $\mathrm{D}_{\text {calc }}$ & $4.55\left(\mathrm{~g} / \mathrm{cm}^{3}\right)$ \\
\hline Molecular weight & $517.7(\mathrm{~g} / \mathrm{mol})$ & $\mathrm{N}^{\circ}$ step intensities & 4001 \\
Crystal system & Orthorhombic & $\mathrm{N}^{\circ}$ independent reflections & 145 \\
Space group & $P m n 2_{1}\left(\mathrm{~N}^{\circ} 31\right)$ & Peak-shape profile & Pseudo-Voigt \\
$\mathrm{Z}$ & 2 & $\mathrm{R}_{\text {exp }} 9.6 \%$ & $10.3 \%$ \\
$\mathrm{a}$ & $8.1705(5) \AA$ & $\mathrm{R}_{p}$ & 1.2 \\
$\mathrm{~b}$ & $6.9413(5) \AA$ & $\mathrm{R}_{w p} 11.8 \%$ & $\mathrm{~S}$ \\
$\mathrm{C}$ & $6.6532(5) \AA$ & $377.33(5)$ & $\mathrm{S}$ \\
\hline
\end{tabular}

$\mathrm{R}_{\exp }=100\left[(\mathrm{~N}-\mathrm{P}+\mathrm{C}) / \sum_{W}\left(y_{\mathrm{obs}}^{2}\right)\right]^{1 / 2} \mathrm{~N}-\mathrm{P}+\mathrm{C}$ is the number of degrees of freedom, $\mathrm{R}_{\mathrm{p}}=100 \sum\left|y_{\mathrm{obs}}-y_{\text {calc }}\right| / \sum\left|y_{\text {obs }}\right|$

$\left.\mathrm{R}_{\mathrm{wp}}=100 \sum_{w}\left|y_{\mathrm{obs}}-y_{\text {calc }}\right| / \sum\left|y_{\mathrm{obs}}\right|\right]^{1 / 2} \mathrm{~S}=\left[\mathrm{R}_{\mathrm{wp}} / \mathrm{R}_{\exp }\right]$

TABLE II. Atomic coordinates, occupancy factors and isotropic temperature factor for $\mathrm{Ag}_{2} \mathrm{MnSnS}_{4}$.

\begin{tabular}{cccccccc}
\hline Atom & Ox. & Wyck. & $x$ & $y$ & $z$ & foc & B $\left(\AA^{2}\right)$ \\
\hline Ag & +1 & $4 b$ & $0.256(2)$ & $0.317(2)$ & 0 & $0.6(1)$ & 1 \\
Mn & +2 & $2 a$ & 0 & $0.848(2)$ & $0.988(2)$ & 1 & $0.6(1)$ \\
Sn & +4 & $2 a$ & 0 & $0.185(2)$ & $0.491(2)$ & 1 & $0.6(1)$ \\
S1 & -2 & $4 b$ & $0.237(2)$ & $0.325(2)$ & $0.387(2)$ & 1 & $0.6(1)$ \\
S2 & -2 & $2 a$ & 0 & $0.186(2)$ & $0.821(2)$ & 1 & $0.6(1)$ \\
S3 & -2 & $2 a$ & 0 & $0.884(2)$ & $0.365(2)$ & 1 & $0.6(1)$ \\
\hline
\end{tabular}

TABLE III. Distance lengths $(\AA)$ and bond angles $\left(^{\circ}\right)$ for $\mathrm{Ag}_{2} \mathrm{MnSnS}_{4}$.

\begin{tabular}{|c|c|c|c|c|c|}
\hline Ag-S1 & $2.58(1)$ & $\mathrm{Mn}-\mathrm{S} 1^{i i i}$ & $2.55(2)$ & $\mathrm{Sn}-\mathrm{S} 1$ & $2.27(2)$ \\
\hline $\mathrm{Ag}-\mathrm{S} 1^{i}$ & $2.60(2)$ & $\mathrm{Mn}-\mathrm{S} 1^{v i}$ & $2.55(2)$ & $\mathrm{Sn}-\mathrm{S} 1^{v i i}$ & $2.27(2)$ \\
\hline $\mathrm{Ag}-\mathrm{S} 2^{i i}$ & $2.57(2)$ & $\mathrm{Mn}-\mathrm{S} 2^{i v}$ & $2.60(2)$ & $\mathrm{Sn}-\mathrm{S} 2$ & $2.20(2)$ \\
\hline $\mathrm{Ag}-\mathrm{S} 3^{i} \mathrm{i}$ & $2.59(2)$ & $\mathrm{Mn}-\mathrm{S} 3^{v}$ & $2.52(2)$ & $\mathrm{Sn}-\mathrm{S} 3^{v i i i}$ & $2.25(2)$ \\
\hline $\mathrm{S} 1-\mathrm{Ag}-\mathrm{S} 1^{i}$ & $105.6(4)$ & $\mathrm{S} 1-\mathrm{Ag}-\mathrm{S} 2^{i i}$ & $114.9(3)$ & $\mathrm{S} 1-\mathrm{Ag}_{-} 3^{i}{ }^{i}$ & $113.8(3)$ \\
\hline $\mathrm{S} 2^{i i}-\mathrm{Ag}-\mathrm{S} 1^{i}$ & $102.8(3)$ & $\mathrm{S} 1^{i}-\mathrm{Ag}-\mathrm{S} 3^{i}$ & $113.4(3)$ & $\mathrm{S} 2^{i i}-\mathrm{Ag}-\mathrm{S} 3^{i}$ & $105.9(3)$ \\
\hline $\mathrm{S} 1^{i i i}-\mathrm{Mn}-\mathrm{S} 1^{v i}$ & $114.7(5)$ & $\mathrm{S} 1^{i i i}-\mathrm{Mn}-\mathrm{S} 2^{i v}$ & $108.2(3)$ & $\mathrm{S} 2^{i v}-\mathrm{Mn}-\mathrm{S} 1^{v i}$ & $108.2(3)$ \\
\hline $\mathrm{S} 3^{v}-\mathrm{Mn}-\mathrm{S} 1^{i i i}$ & $108.0(3)$ & $\mathrm{S} 3^{v}-\mathrm{Mn}-\mathrm{S} 1^{v i}$ & $108.0(3)$ & $\mathrm{S} 3^{v}-\mathrm{Mn}-\mathrm{S} 2^{i v}$ & $109.7(7)$ \\
\hline $\mathrm{S} 2-\mathrm{Sn}-\mathrm{S} 1$ & $107.6(3)$ & $\mathrm{S} 2-\mathrm{Sn}-\mathrm{S} 3^{v i i i}$ & $112.0(8)$ & $\mathrm{S} 1-\mathrm{Sn}-\mathrm{S} 3^{v i i i}$ & $106.5(4)$ \\
\hline $\mathrm{S} 1^{v i i}-\mathrm{Sn}-\mathrm{S} 2$ & $107.6(3)$ & $\mathrm{S} 1^{v i i}-\mathrm{Sn}-\mathrm{S} 1$ & $116.7(6)$ & $\mathrm{S}^{v i i}-\mathrm{Sn}-\mathrm{S} 3^{v i i i}$ & $106.5(4)$ \\
\hline
\end{tabular}

Symmetry codes: (i) $0.5-x, 1-y,-0.5+z$; (ii) $x, y,-1+z$; (iii) $-0.5+x, 1-y, 0.5+z$; (iv) $x, 1+y, z$; (v) $x, y, 1+z ;$ (vi) $0.5-x, 1-y, 0.5+z$; (vii) $-x, y, z$; (viii) $x,-1+y, z$.

the Cagliotti's formula [45]. The parameterized ThompsonCox-Hastings pseudo-Voigt profile function [46] was used for the simulation of the peak shapes. The background of the XRD data was refined with a polynomial with six coefficients. The thermal motion of the atoms was described by one overall isotropic temperature factor. A total of 23 parameters of the $\mathrm{Ag}_{2} \mathrm{MnSnS}_{4}$ compound, including peak shape, scale factor, cell, atomic coordinates, isotropic displacement and full-width at half-maximum (FWHM) parameters, were refined. The final Rietveld refinement led to agreement factors of: $\mathrm{R}_{\mathrm{p}}=10.3 \%, \mathrm{R}_{\mathrm{wp}}=11.8 \%, \mathrm{R}_{\mathrm{exp}}=9.6 \%$, and $\mathrm{S}=1.2$, for 4001 step intensities and 145 independent reflections.
The results of the Rietveld refinement are summarized in Table I. Figure 3 shows the observed calculated and difference profile for the final cycle of the refinement. Atomic coordinates, occupancy factors and isotropic temperature factor are given in Table II. Bond distances and angles are given in Table III. Figure 4 shows the unit cell diagram for $\mathrm{Ag}_{2} \mathrm{MnSnS}_{4}$.

$\mathrm{Ag}_{2} \mathrm{MnSnS}_{4}$ crystallize with orthorhombic symmetry, space group $P m n 2_{1}$, and unit cell parameters: $a=8.1705(5)$ $\AA, b=6.9413(5) \AA, c=6.6532(5) \AA$, and $V=377.33(5) \AA^{3}$ in a wurtzite-stannite structure. This structure can be described as a hexagonal, closest-packed array of sulfur anions with 


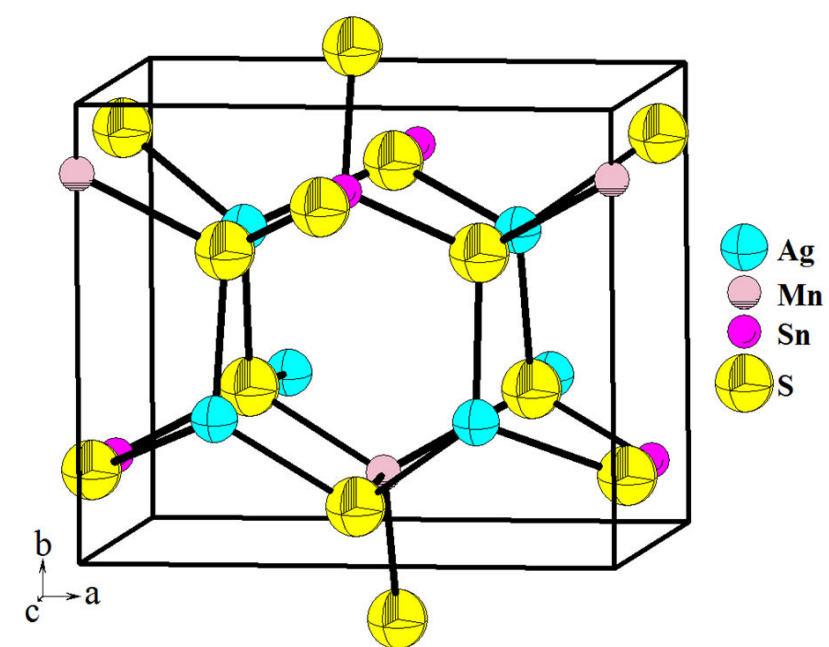

FIGURE 4. Unit cell diagram of $\mathrm{Ag}_{2} \mathrm{MnSnS}_{4}$ viewed in the $b a$ plane of the space group $\operatorname{Pmn} 2_{1}$.

$\mathrm{Ag}^{+}, \mathrm{Mn}^{+2}$ and $\mathrm{Sn}^{4+}$ occupying tetrahedral holes, and is characterized by a three-dimensional arrangement of slightly distorted $\mathrm{AgS}_{4}, \mathrm{MnS}_{4}$ and $\mathrm{SnS}_{4}$ tetrahedra connected by corners. All $\mathrm{S}$ atoms are surrounded by two Ag atoms and by one $\mathrm{Mn}$ and one Sn atom, and each cation is coordinated by 4 anions. This array is expected for adamantane compounds [1].

The tetrahedrons containing the $\mathrm{Sn}$ atoms [mean S...S distance $3.67(2) \AA]$ are slightly smaller than those containing the Mn atoms [means S. . .S distance 4.16(2) $\AA$ ] and Ag atoms [mean S. . S distance 4.22(2) $\AA$ ] respectively. The interatomic distances are shorter than the sum of the respective ionic radii $\left(r \mathrm{Ag}^{+}=1.14, r \mathrm{Mn}^{2+}=0.80, r \mathrm{Sn}^{4+}=0.69\right.$, $r \mathrm{~S}^{2-}=1.70 \AA$ ) for structures tetrahedrally bonded [47].

The mean bond distance values for $\mathrm{Ag}-\mathrm{S}, \mathrm{Mn}-\mathrm{S}$ and $\mathrm{Sn}-\mathrm{S}$, given in Table III, agree well with the distances observed in other adamantane compounds as $\mathrm{Ag}_{2} \mathrm{CdSnS}_{4}$ [9], $\mathrm{Ag}_{2} \mathrm{CdGeS}_{4}$ [29], $\mathrm{Ag}_{2} \mathrm{CdSnS}_{4}$ [30], $\mathrm{Ag}_{2} \mathrm{ZnSiS}_{4}$ [32], $\mathrm{AgCd}_{2} \mathrm{GaS}_{4}$ [48], $\mathrm{Ag}_{2} \mathrm{ZnGeS}_{4}$ [49], $\mathrm{MnIn}_{2} \mathrm{~S}_{4}$ [50], $\mathrm{AgInS}_{2}$ and $\mathrm{AgIn}_{5} \mathrm{~S}_{8}$ [51].

In addition, the Debye temperature $\theta_{D}$, which is an important parameter in the understanding of thermal and electrical properties of semiconducting materials, can be estimated for this compound by using the Lindemann's expression $\theta_{D} \approx C\left(T_{M} / \bar{W}\right)^{1 / 2}\left(1 / a_{e}\right)[52]$. Here, $\bar{W}=W / n, W$ is the molecular weight, $n$ is the number of atoms per molecule ( $n=8$ for $\mathrm{Ag}_{2} \mathrm{MnSnS}_{4}$ ), $C$ is a constant $(C \approx 300$ for $\mathrm{I}_{2}$-II-IV-VI ${ }_{4}$ tetrahedral bonded quaternary compounds [24]), and ae is the effective lattice parameter $a_{e}=(V / Z)^{1 / 3}$, where $V$ is the volume of unit cell (in $\AA^{3}$ ) and $Z$ the number of molecules per cell $(Z=2)$. For $\mathrm{Ag}_{2} \mathrm{MnSnS}_{4}$, from the calculated value $a_{e}=5.7354 \AA$, we obtain $\theta_{D} 212 \mathrm{~K}$. This value is in good agreement with those reported for the related $\mathrm{Cu}_{2} \mathrm{Mn}-\mathrm{IV}-\mathrm{VI}_{2}$ semimagnetic semiconductor compounds, which vary from 185 to $310 \mathrm{~K}$ [24].

\section{Conclusions}

The quaternary chalcogenide compound $\mathrm{Ag}_{2} \mathrm{MnSnS}_{4}$ crystallizes in the wurtzite-stannite structure, space group $P m n 2_{1}$, characterized by a three-dimensional arrangement of slightly distorted $\mathrm{AgS}_{4}, \mathrm{MnS}_{4}$ and $\mathrm{SnS}_{4}$ tetrahedras connected by corners. The DTA indicates that this compound melts at $790^{\circ} \mathrm{C}$.

\section{Acknowledgments}

This work was supported by CDCHT-ULA FONACIT (Grant LAB-97000821).
1. E. Parthé: Wurtzite and Sphalerite Structures. In: J.H. Westbrook, R.L. Fleischer (Eds), Intermetallic Compounds, Principles and Applications. Vol. 1, John Wiley \& Sons, Chichester, UK, Chap. 14 (1995).

2. Q. Guo, W.W. Hillhouse, R. Agrawal, J. Am. Chem. Soc. 131 (2009) 11672.

3. S. Ahn et al., App. Phys. Letters, 97 (2010) 021905.

4. T.K. Todorov, K.B. Reuter, and D.B. Mitzi, Adv. Mater. 22 (2010) E156.

5. I. Tsuji, Y. Shimodaira, H. Kato, H. Kobayashi, and A. Kudo, Chem. Mater. 22 (2010) 1402.

6. X.Y. Shi, F.Q. Huang, M.L. Liu, and L.D. Chen, App. Phys. Letters, 94 (2009) 122103.

7. C. Sevik and T. Cagin, Phys. Rev. B, 82 (2010) 045202.

8. M. Ibáñez et al., Chem. Mater. 24 (2012) 562.

9. G.E. Davydyuk et al., Opt. Mater. 33 (2011) 1302.

10. W. Liu et al., Thin Solid Films 535 (2013) 39.
11. M. Wei et al., Mater. Letters 79 (2012) 177.

12. S.R. Hall, J.T. Szymanski, and J.M. Stewart, Can. Mineral. 16 (1978) 131.

13. E. Parthé, K. Yvon, and R.H. Deitch, Acta Cryst. B 25 (1969) 1164.

14. C.A. Joubert-Bettan, R. Lachenal, E.F. Bertaut, and E. Parthé, J. Solid State Chem. 1 (1969) 1.

15. S. Chen, X.G. Gong, A. Walsh, and S-H. Wei, Phys. Rev. B, 79 (2009) 165211.

16. S. Chen et al., Phys. Rev. B, 82 (2010) 195203.

17. E. Quintero et al., Phys. B: Cond. Matter, 320 (2002) 384.

18. G.E. Delgado, E. Quintero, R. Tovar, and M. Quintero, Cryst. Res. Technol. 39 (2004) 807.

19. E. Quintero et al., J. Alloys Comp. 432 (2007) 142.

20. M. Quintero et al., Ciencia, 15 (2007) 222.

21. D. Caldera et al., J. Alloys Comp. 457 (2008) 221. 
22. E. Moreno et al., J. Alloys Comp. 486 (2009) 212.

23. C. Rincón et al., Solid State Comm. 151 (2011) 947.

24. M. Quintero et al., Rev. LatinAm Met. Mater. 34 (2014) 28.

25. F. López-Vergara, A. Galdámez, V. Manríquez, P. Barahona, and O. Peña, phys. stat. sol. (b) 251 (2014) 958.

26. Y. Dong, L. Wojtas, J. Martin, and G.S. Nolas, J. Mater. Chem. 3 (2015) 10436.

27. K. Wei and G.S. Nolas, J. Solid State Chem. 226 (2015) 215.

28. O.V. Parasyuk, L.D. Gulay, L.V. Piskach, and I.D. Olekseyuk, J. Alloys Comp. 397 (2005) 95.

29. O.V. Parasyuk, L.V. Piskach, I.D. Olekseyuk, and V.I. Pekhnyo, J. Alloys Comp. 335 (2002) 176.

30. G.E. Davydyuk et al., Opt. Mater. 33 (2011) 1302.

31. C.D. Brunetta, W.C. Minsterman, C.H. Lake, and J.A. Aitken, J. Solid State Chem. 187 (2012) 177.

32. C.D. Brunetta, K. Balamurugan, K.A. Rosmus, and J.A. Aitken, J. Alloys Comp. 516 (2012) 65.

33. C.D. Brunetta et al., J. Alloys Comp. 574 (2013) 495.

34. K. Wei and G.S. Nolas, ACS App. Mater. \& Interfaces 7 (2015) 9752.

35. K. Wei, A.R. Khabibullin, T. Stedman, L.M. Woods, and G.S. Nolas, J. Appl. Phys. 122 (2017) 105109.

36. Y. Shapira et al., Phys. Rev. B 37 (1988) 411.

37. M. Lamarche, A. Willsher, L. Chen, G. Lamarche, and J.C. Woolley, J. Solid State Chem. 94 (1991) 313.

38. S. Greil and A. Pfitzner, Z. Anorg. Allg. Chem. 638 (2012) 1570. Abstracts of the 16th Conference of the GDCh Division for Solid State Chemistry and Materials Research, Darmstadt, Germany, Sept. 2012.
39. R. Caye, Y. Laurent, P. Picot, R. Pierrot, and C. Levy, Bull. Soc. Fran. Minér. Crist. 91 (1968) 383.

40. Z. Johan, and P. Picot, Bull. Minér. 105 (1982) 229.

41. F.N. Keutsch, D. Topa, R. Takagi, E. Makovicky, and W. Paar, Agmantinite IMA 2014-083 Commission on New Minerals, Nomenclature and Classification (CNMNC) Newsletter No. 23, Feb. 2015, page 57. Mineral. Mag. 79 (2015) 51.

42. A. Boultif and D. Louër, J. App. Cryst. 37 (2004) 724.

43. H.M. Rietveld, J. App. Cryst. 2 (1969) 65.

44. J. Rodriguez-Carvajal, Phys. B: Cond. Matter 192 (1993) 55.

45. G. Cagliotti, A. Paoletti, and F.P. Ricci, Nucl. Instrum. 3 (1958) 223.

46. P. Thompson, D.E. Cox, and J.B. Hastings, J. App. Cryst. 20 (1987) 79.

47. S.D. Shannon, Acta Cryst. A 32 (1976) 751.

48. N.V. Pervukhina, V.V. Atuchinb, and O.V. Parasyuk, Acta Cryst. E 61 (2005) i91.

49. O.V. Parasyuk, A.O. Fedorchuk, Yu.M. Kogut, L.V. Piskach, and I.D. Olekseyuk, J. Alloys Comp. 500 (2010) 26.

50. V. Sagredo, M.C. Morón, L. Betancourt, and G.E. Delgado, J. Mag. Mag. Mater. 312 (2007) 294.

51. G.E. Delgado, A.J. Mora, C. Pineda, and T. Tinoco, Mater. Res. Bull. 36 (2001) 2507.

52. P. Deus, H.A. Schneider, and U. Voland, Cryst. Res. Technol. 16 (1981) 941 